\title{
People who Appear in this Book
}

\section{Iraqis}

Muhammad Yunus al-Ahmad

Senior Ba'athist rumoured to be living in Syria. One of the key planners of the insurgency.

\section{Ali Allawi}

Served as minister of trade and later minister of defence in the Cabinet of the Governing Council. Member of the Transitional National Assembly. Minister of finance in the Transitional National Government.

\section{Ayad Allawi}

Former head of the INA. Close to western and Arab governments. Member of the Governing Council. Prime minister of the Interim Government. Head of the Iraqiyya parliamentary list.

\section{Massoud Barzani}

Son of the legendary Kurdish fighter and leader Mulla Mustafa Barzani. Head of the KDP. A strong advocate of maximum Kurdish autonomy. Leader of the Kurdistan Regional Government.

\section{Ahmad Chalabi}

Brilliant but controversial leader of the INC. Served on the Governing Council. Later broke with the Americans, only to re-emerge as deputy prime minister in the Transitional National Government.

\section{Salem Chalabi}

Iraqi lawyer and first director of the Iraq Special Tribunal.

\section{Hareth al-Dhari}

Leader of the Association of Muslim Scholars. A radical Sunni Arab opponent of the occupation.

\section{Izzat al-Douri}

Senior Ba'athist and former vice-president of Iraq. Escaped capture and rumoured to be a linchpin of the insurgency.

\section{Adnan al-Dulaimi}

Religious leader and former head of the Sunni Endowment Association. Leader of the Tawaffuq bloc in parliament. 


\section{Faisal I, King of Iraq}

Ensconced on the Iraqi throne in 1921 by the British. Understood the difficulties of governing Iraq's fractured society, and sought to overcome the divisions of his adopted country by building strong state institutions.

\section{Abdul Aziz al-Hakim}

Assumed leadership of SCIRI after the murder of his brother, Ayatollah Baqir al-Hakim. Head of the Shi'a United Iraqi Alliance parliamentary group.

\section{Ayatollah Baqir al-Hakim}

Leading Islamist opponent of the Ba'athist regime. Went into exile in Iran. Helped to found SCIRI, which he led for over two decades. Returned to Iraq to popular acclaim in May 2003. Killed by a powerful car bomb in Najaf, August 2003.

\section{Mahdi al-Hakim}

Son of the Grand Ayatollah Muhsin al-Hakim. Prominent in organising the Iraqi opposition to Saddam Hussein in the 1980s. Assassinated in 1988 in Khartoum by Ba'ath regime agents.

\section{Tarek al-Hashemi}

Leader of the Iraq Islamic Party, an offshoot of the Muslim Brotherhood. Closely connected to the American plan to increase Sunni participation in government. Vicepresident of Iraq 2006.

\section{Saddam Hussein}

Dictator of Iraq for nearly thirty years. His bloody rule was ended by the Coalition invasion of 2003. Brought in front of the Iraq Special Tribunal on charges of war crimes and crimes against humanity. Sentenced to death in November 2006.

\section{Ibrahim al-Jaafari}

Leader of the Da'awa Party and member of the Governing Council. First elected prime minister of Iraq following the January 2005 elections for a Transitional National Assembly. Blocked from a second premiership, to which he had been elected, by a US and British veto.

\section{Grand Ayatollah Abu al-Qasim al-Khoei}

The undisputed leader of the world's Shi'a. Followed the 'quiescent' tradition in Shi'a Islam by avoiding political entanglements. Was decisively opposed to the Khomeini proposition of direct rule by learned clerics.

\section{Adel Abd el-Mahdi}

Principal SCIRI political strategist. Served as minister of finance in the Interim Government of Ayad Allawi. He was later the vice-president of Iraq.

\section{Kenan Makiya}

Writer and public intellectual. Author of The Republic of Fear, a powerful indictment of the Ba'ath rule in Iraq.

\section{Nuri (Jawad) al-Maliki}

Senior Da'awa Party leader. Spent two decades in Syria in exile before returning to Iraq. Served on the de-Ba'athification Commission and headed the Transitional National Assembly's security committee. Unexpectedly propelled to the premiership in May 2006 after the Anglo-American veto on Jaafari.

\section{Abu Muhammad al-Maqdisi}

Palestinian-born Islamist ideologue. A strong influence on jihadi thought and a mentor of Zarqawi. Later, he reputedly recanted some of his extremist views. 


\section{Adnan al-Pachachi}

Veteran liberal politician. Served as foreign minister of Iraq in the 1960s. Member of the Governing Council and elected to the four-year parliament on Ayad Allawi's Iraqiyya list.

\section{Latif Rashid}

Senior PUK leader. Served as the minister of water resources in all Iraq's governments after the fall of Saddam.

\section{Mowaffaq Rubai'e}

Independent Islamist, formerly a senior Da'awa Party leader. Member of the Governing Council. Appointed the national security adviser in 2004. Member of the UIA bloc and close adviser to Nuri al-Maliki.

\section{Ayatollah Muhammad Baqir al-Sadr}

A leading figure in Islamic thought of the twentieth century. Associated with the rise of the Iraqi Shi'a Islamist movement. Murdered by the Ba'athist regime in 1980.

\section{Moqtada al-Sadr}

Son of Ayatollah Muhammad Sadiq al-Sadr and head of the amorphous anti-occupation Sadrist movement and its Mahdi Army. Leader of a large parliamentary bloc and a force behind the Maliki government.

\section{Ayatollah Muhammad Sadiq al-Sadr}

Populist Grand Ayatollah, who built up a massive following in the 1990s. Murdered by assassins from the Saddamist intelligence agencies in 1999. Contrary to expectations, the movement associated with him continued in strength after his death.

\section{Muhammad Shahwani}

Former general in the Iraqi army. Implicated in a 1996 coup attempt against the Ba'ath regime. Rumoured to be close to the CIA. Head of the new Iraqi intelligence apparatus.

\section{Grand Ayatollah Sayyid Ali al-Sistani}

The acknowledged religious leader of Iraq's Shi'a over the last decade. Played a vital role in pushing for an elected constitutional order after the invasion of Iraq.

\section{Muhammad Redha Sistani}

Son of Grand Ayatollah Ali Sistani and head of his private office, from which he wields considerable influence.

\section{Jalal Talabani}

Historic Kurdish political leader and head of the PUK. Member of the Governing Council. President of Iraq from 2005 onwards.

\section{Ali al-Wardi}

Iraqi sociologist and social historian. Known for his monumental work on Iraq's social history and his dissection of the Iraqi identity.

\section{Abu Musab al-Zarqawi \\ Jordanian-born terrorist leader and head of the al-Qaeda organisation in Iraq. Killed in a US air-strike in June 2006. \\ Others \\ Tony Blair \\ British prime minister. Abandoned traditional British caution and followed the lead of George W. Bush in advocating war on Iraq.}




\section{Lakhdar Brahimi}

Algerian diplomat and UN troubleshooter. Involved in the process that led to the formation of the Interim Government and the transfer of sovereignty to Iraq.

\section{Paul Bremer}

Diplomat and counter-terrorism expert. Headed the Coalition Provisional Administration, the occupying government in Iraq from May 2003 to June 2004.

\section{George W. Bush}

President of the United States. The person most singly responsible for the Iraq war and its aftermath.

\section{Douglas Feith}

Neo-conservative lawyer and head of the Pentagon's Office of Special Plans. Was effectively responsible for the planning for Iraq's post-war occupation.

\section{Jay Garner}

Retired US Army general and head of ORHA, the first post-war administration for Iraq. Unfairly maligned for his perceived bungling of the job.

\section{Zalmay Khalilzad}

Afghan-born American public official and diplomat. Close to neo-conservative circles. Served as liaison with the Iraqi opposition in 2002 and 2003. Appointed the American ambassador to Iraq in 2005.

\section{Bernard Lewis}

Leading historian of the Middle East. Wielded great influence on neo-conservative thinking on Iraq and on Vice-President Cheney directly.

\section{Robert Merton}

A prominent American sociologist who was instrumental in defining the term 'The Law of Unexpected Consequences'.

\section{Colin Powell}

US secretary of state. Maintained a sceptical position on the war, but eventually went along with it.

\section{Condoleezza Rice}

US national security adviser and later secretary of state in the second Bush administration.

\section{Donald Rumsfeld}

US secretary of defense. Was held responsible for the inadequate size of the American force that occupied Iraq.

\section{Leo Strauss}

German-born scholar and philosopher associated with the University of Chicago. His political philosophy was a major influence on a number of senior Bush administration officials

\section{Paul Wolfowitz}

US deputy secretary of defense. A strong advocate of the war against Iraq and the implantating of democratic principles into the politics of the Islamic world. 